\title{
Universiteit
}

Leiden

The Netherlands

\section{Additive and Non-Additive Risk Factors in Multiple Causation}

Velthoven, B.C.J. van; Wijck, P.W. van

\section{Citation}

Velthoven, B. C. J. van, \& Wijck, P. W. van. (2009). Additive and Non-Additive Risk Factors in Multiple Causation. Review Of Law \& Economics, 5(1), 517-539. Retrieved from https://hdl.handle.net/1887/43346

Version: $\quad$ Not Applicable (or Unknown)

License:

Downloaded from: https://hdl.handle.net/1887/43346

Note: To cite this publication please use the final published version (if applicable). 


\title{
Additive and Non-Additive Risk Factors in Multiple Causation
}

\author{
BEN C.J. VAN VELTHOVEN, PETER W. VAN WIJCK* \\ Leiden University, The Netherlands
}

The law and economics literature on multiple causation generally distinguishes between causal uncertainty and joint causation. For cases of causal uncertainty it has been shown that proportional liability, a fractional share rule, may lead to socially optimal incentives for the level of care. However, for cases of joint causation fractional share rules tend to be inefficient. This paper argues that the crucial distinction is not so much between the uncertainty or jointness of the causal elements, but rather between the additivity or non-additivity of risk factors. We develop an approach that integrates causal uncertainty and joint causation. We show that an apportionment rule that assigns liability in proportion to the probability of causation always yields efficient incentives when the risk factors are additive. In non-additive cases the proportional rule has an efficient equilibrium outcome (and this equilibrium is unique for almost all parameter settings) when tortfeasors act independently and simultaneously. But it is not always efficient when tortfeasors act in concert or act sequentially. We apply our approach to four recent cases from English jurisprudence. These cases illustrate that both causal uncertainty and joint causation may involve additive as well as non-additive risks.

\section{INTRODUCTION}

In different types of cases, it appears to be impossible to attribute harm to a single cause. First, in cases of causal uncertainty there are two or more possible causes for the victim's harm, at least one of which is related to (allegedly) tortious behavior; the evidence may turn out to be insufficient to determine the actual cause with any degree of certainty. This is quite different from cases of joint causation where it may be crystal clear how the interaction of two or more causal factors was responsible, either concurrently or sequentially, for

\footnotetext{
* We thank an anonymous referee and an editor of this journal for very helpful comments. Contact info: Department of Economics, Faculty of Law, Leiden University, PO Box 9520, 2300 RA Leiden, The Netherlands; b.c.j.vanvelthoven@law.leidenuniv.nl; p.w.vanwijck@law.leidenuniv.nl.
} 
one specific (non-distinct) harm. Both types of multiple causation, causal uncertainty and joint causation, however, give rise to a similar problem: If we want to stimulate parties to take (ex ante) efficient measures to prevent harm, who should (ex post) bear which share of the harm?

This problem has been studied in the law and economics literature along two different lines of research. See, most notably, Shavell (1985) for causal uncertainty and Kornhauser \& Revesz (1989) and Miceli \& Segerson (1991) for joint causation. Their findings suggest that the liability shares of the causes should sum to 1 in cases of causal uncertainty, while the sum might either be greater or smaller than 1 in cases of joint causation. More recently, Young et al. $(2004,2007)$ have set out to develop a unifying framework. Although their findings confirm the results from earlier work, there are also several reasons why their analysis is not conclusive. Most importantly, it is not made clear what is the essential factor determining whether or not the liability shares should sum to one. We argue that the crucial distinction is between additive and nonadditive risk factors.

Parisi and Fon (2004) make a similar distinction in their analysis of comparative causation. They distinguish between cases where the overall causation factor is the sum of the parties' causal inputs and cases where it is the product of the parties' causal inputs. In both types of cases, however, parties may be led to choose inefficient levels of care. The reason for this inefficiency appears to be that the comparative causation rule as it is adopted by Parisi and Fon does not fully internalize the contribution to expected harm when harm itself is also a function of the parties' levels of care.

In this paper we develop an approach to the study of multiple causation that integrates the analysis of causal uncertainty and joint causation. We consider cases where expost several actors or factors allegedly have contributed in any combination or other to the occurrence of harm. In essence we then make a reconstruction of the situation ex ante and analyze how tort law might have given efficient incentives in the case. It is shown that a proportional apportionment rule, where each tortfeasor pays a fraction of the harm that corresponds with his proportional contribution to the ultimate risk, ${ }^{1}$ always yields efficient incentives in cases of additivity. In non-additive cases the proportional rule has an efficient equilibrium outcome (and this equilibrium is unique for almost all parameter settings) when tortfeasors act independently and simultaneously, provided a third party is being present to collect or make

\footnotetext{
${ }^{1}$ In the general sense of his proportional contribution to expected harm, either because the tortfeasor's behavior increased the probability of harm and/or because it contributed to the amount of harm.
} 
Additive and Non-Additive Risk Factors in Multiple Causation / 519

up for any difference between the total apportionment of damages and actual harm. The proportional rule is not always efficient when tortfeasors act in concert. Nor does it always provide efficient incentives when tortfeasors act sequentially and the first actor can take the situation as he finds it, not anticipating (and being held liable for) any tortious act following his own.

The paper is organized as follows. In Section 2 we discuss the law and economics literature on multiple causation. We then present our own approach, in Section 3 for cases of additivity and in Section 4 for cases of nonadditivity. In Section 5 we demonstrate how our approach may be used in practice, by applying it to some recent cases from English jurisprudence. Section 6 concludes.

\section{HISTORICAL PERSPECTIVE}

Ever since Rizzo \& Arnold (1980) and Landes \& Posner (1980), the law and economics literature has been concerned with the proper apportionment of tort damages in cases of multiple causation. ${ }^{2}$ Two somewhat different, but related lines of research can be distinguished.

For cases of causal uncertainty Shavell $(1985)^{3}$ argues that from an efficiency point of view proportional liability is superior to any all-or-nothing criterion and thus in particular, to any threshold probability criterion. Liability in proportion to the probability of causation results in parties' facing expected liability equal to the expected harm they impose. Hence, it leads to socially optimal incentives for the level of care. The more general problem of excessive incentives to engage in risky activities remains, if proportional liability is introduced within a system of negligence rather than strict liability. Shavell also notes that proportional liability has a disadvantage in that it may lead to a substantial increase in the volume, complexity, and cost of litigation. Any party for which the probability of having caused the harm is positive may be sued for damages.

For cases of joint causation Kornhauser \& Revesz (1989) argue that under negligence with the standards of care set at the socially optimal level any unitary share rule (joint liability with or without contribution) will yield efficient incentives to take care, while a fractional share rule (no-joint liability) will not. Under strict liability, existing unitary and fractional share rules will both tend to be inefficient. They propose an alternative apportionment rule that might produce efficient incentives under strict liability. Under that rule, the full harm is divided per capita among the various actors when none exceeds the socially optimal level of care.

\footnotetext{
2 See Ben-Shahar (2000) and Kornhauser \& Revesz (2000) for an overview.

${ }^{3}$ See also Shavell (2004).
}

DOI: $10.2202 / 1555-5879.1340$ 
But if some actors cross this threshold, then those actors divide the full harm per capita among themselves, while the remaining actors pay nothing. Miceli \& Segerson (1991) consider yet another modification of strict liability that would induce joint tortfeasors to choose both efficient levels of care and of activities. Under their apportionment rule each tortfeasor pays a sum equal to the difference between actual harm and the harm that would have resulted were he inactive. That is, each tortfeasor is held liable for the full amount of harm, but he receives a 'credit' for the expected harm that would have occurred in his absence. Since this rule may lead to damage payments exceeding actual harm, the state is needed as a third party to collect the surplus by way of fine.

More recently, Young et al. $(2004,2007)$ have reanimated the discussion, within a setting of strict liability. Young et al. (2004) concentrate on causal uncertainty. They go into some depth to present a topological model to distinguish the various factors that may lead to harm. See Figure 1. Actor A may or may not engage in a tortious act. If he does, it can through the working of nature $A^{\text {' }}$ (probability q) and the interference of the victim B (probability p) cause harm $\mathrm{H}$. As harm will arise only if $A^{\prime}$ and $B$ occur, and not otherwise, $A$ in itself is not sufficient. A need not be necessary either, as in the absence of A there may be another cause $C$ (probability $1-\pi$ ) which through the interference of victim B could also produce the harm.

Figure 1. Various Factors Leading to Harm

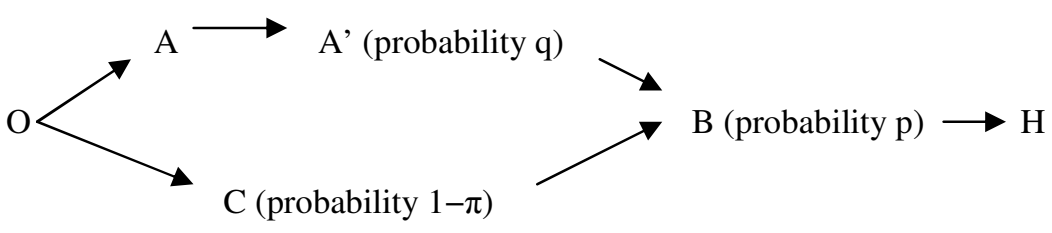

The probability of causation by actor $A$ is calculated as $[p(H \mid A)$ $\mathrm{p}(\mathrm{H} \mid \sim \mathrm{A})] / \mathrm{p}(\mathrm{H} \mid \mathrm{A})$, with $\mathrm{p}(\mathrm{H} \mid \mathrm{A})$ the probability of harm if the act by $\mathrm{A}$ is committed and $\mathrm{p}(\mathrm{H} \mid \sim \mathrm{A})$ the probability of harm but for the act by A. In short: it is the excess risk as a fraction of the sum of the background risk plus the excess risk. If the various risk factors in Figure 1 work statistically independent from one another, it follows that $\mathrm{p}(\mathrm{H} \mid \mathrm{A})=[\mathrm{q}+(1-\mathrm{q})(1-\pi)] \mathrm{p}=[1-(1-\mathrm{q}) \pi] \mathrm{p}$, while $\mathrm{p}(\mathrm{H} \mid \sim \mathrm{A})=(1-\pi) \mathrm{p}$. Proportional liability produces social efficiency, if and only if the proportion of damages to be paid by $A$ upon his tortious act is determined on the basis of the probability of causation, $q \pi /[1-(1-q) \pi]$.

Young et al. (2007) study cases of joint causation. They apply the framework from their 2004 paper to derive an 'exhaustive' classification of the way in 
which two tortious acts may combine with each other. Thereto a second actor $\mathrm{E}$ is introduced in Figure 1, which through the working of nature E' (probability r) may contribute to the risk of harm. As the act of $\mathrm{E}$ may take the place of either $\mathrm{A}^{\prime}$ or $\mathrm{B}$ or $\mathrm{C}$ in the framework, and as the act of $\mathrm{E}$ may either precede or be concurrent with or follow the act of $A$, the authors end up with nine combinations of topological and chronological relationships between the acts of $\mathrm{A}$ and $\mathrm{E}$, one of which is redundant. The apportionment of liability required for efficient incentives in respect to any one tortfeasor depends on how that tortfeasor's contribution towards the harm connects with the acts or omissions of the other tortfeasor. It is shown that with efficient apportionment the sum of damage payments by the tortfeasors is generally either greater or smaller than the actual harm.

Young et al. must be applauded for their effort to try and develop a unifying framework for the study of different instances of multiple causation. It is reassuring that the findings confirm the earlier results by Shavell (1985) for causal uncertainty and by Miceli \& Segerson (1991) for joint causation. But there are also several reasons to criticize their approach. First, it is not made clear why the liability shares of the causes should sum to 1 in cases of causal uncertainty, and to an amount either greater or smaller than 1 in cases of joint causation. We conjecture that it is the additivity or non-additivity of the risk factors which plays the crucial role here.

Second, the setting of the interplay between the causal factors is rather restrictive. For uncertain causation the various risk factors in Figure 1 are taken to work statistically independent from one another. For joint causation it is assumed that each tortfeasor knows of the other's conduct in instances of concurrent torts and simultaneous acts. When the acts occur sequentially, however, each tortfeasor takes the situation as he finds it. In particular, he does not anticipate the act of the other tortfeasor. We conjecture that it would be more illuminating to replace the framework of Figure 1 by an explicit game-theoretic setting.

Third, the authors claim that their classification is exhaustive. In that respect, however, their heavy emphasis on the probability of causation is inappropriate. As their framework centers on the probability of harm, the amount of harm, if any, is taken to be constant. That is a real simplification, because one can easily conceive of cases of joint causation where it is the amount of harm that varies. For reasons of exposition, our own analysis will also start from an invariant amount of harm. But our framework can be directly adopted for an analysis in terms of (additions to) expected harm.

Starting from these three observations, we will develop an approach to the study of multiple causation that integrates the analysis of causal uncertainty and joint causation. We consider cases where expost several actors or factors allegedly

DOI: $10.2202 / 1555-5879.1340$ 
have contributed in any combination or other to the occurrence of harm. Our central question is how tort law may be used to give ex ante incentives to induce efficient behavior in this type of cases. We will start in section 3 with the relatively simple case where the various risk factors contribute additively to expected harm. Non-additivity will be addressed in Section 4.

\section{ADDITIVITY}

Consider a case where victim B has suffered harm H. Expost it is clear that the harm may have been caused by the careless behavior of injurer $\mathrm{A}$, but victim $\mathrm{B}$ himself has also acted carelessly. ${ }^{4}$ Upon the facts the ultimate cause cannot be identified with certainty. What fraction of harm should be apportioned to A and $\mathrm{B}$ in order to give them efficient incentives? To answer this question, we make an $e x$ ante reconstruction.

Suppose that ex ante the probability of harm depends on the behavior of the two actors, A and B. Each actor has the dichotomous choice either to act with care or to act carelessly. Let $\mathrm{p}_{0}$ be the probability that nature (e.g. genetic predisposition or mere chance) causes harm if neither A nor B acts carelessly. If only $\mathrm{A}$ acts without care, the probability of harm increases by $\mathrm{p}_{\mathrm{A}}$, i.e. $\mathrm{p}_{0 \mathrm{~A}}=$ $\mathrm{p}_{0}+\mathrm{p}_{\mathrm{A}}$. If only $\mathrm{B}$ acts carelessly, the probability of harm increases by $\mathrm{p}_{B}$, i.e. $\mathrm{p}_{0 \mathrm{~B}}$ $=\mathrm{p}_{0}+\mathrm{p}_{\mathrm{B}}$. In the additive case, the increase in the probability of harm that results when both individuals engage in careless behavior is equal to the sum of the increases in the probability of harm when each actor engages in careless behavior, i.e. $\mathrm{p}_{0 \mathrm{AB}}=\mathrm{p}_{0}+\mathrm{p}_{\mathrm{A}}+\mathrm{p}_{\mathrm{B}}$. Table 1 summarizes the probabilities of harm.

Table 1. Probabilities of Harm in Additive Case

\begin{tabular}{|c||c|c|c|}
\hline \multicolumn{2}{|c|}{} & \multicolumn{2}{|c|}{ Victim B } \\
\cline { 3 - 4 } \multicolumn{2}{|c|}{} & Careful & Careless \\
\hline \multirow{2}{*}{ Injurer A } & Careful & $p_{0}$ & $p_{0 B}=p_{0}+p_{B}$ \\
\cline { 2 - 4 } & Careless & $p_{0 A}=p_{0}+p_{A}$ & $p_{0 A B}=p_{0}+p_{A}+p_{B}$ \\
\hline
\end{tabular}

\footnotetext{
${ }^{4}$ The analysis can almost directly be applied to a case with two potential injurers, without the victim contributing to the probability of harm. A slightly different interpretation of the role of actor B suffices. The analysis can also be easily adapted to cases with more than two causal factors. Moreover, the formulation is general enough to cover both negligence and strict liability.
} 
We further assume that harm, if it occurs, is always equal to H. ${ }^{5}$ The net benefits from careless behavior (relative to acting with care) will be denoted by $\mathrm{N}_{\mathrm{A}}$ and $\mathrm{N}_{\mathrm{B}}$.

Given the reconstruction of the situation ex ante, we now consider how the tort system may provide efficient incentives.

In the upper left cell of Table 1 both A and B act carefully. Due to nature the victim may still be confronted with harm. All harm can be left where it falls, that is with the victim, as there are no incentive effects at stake. Consequently, A's expected payoff is 0 , while $B$ is faced with the expected harm $\mathrm{p}_{0} \mathrm{H}$.

In the upper right cell $\mathrm{A}$ once again acts carefully, implying that he does not contribute to the risk of harm. B, however, engages in careless behavior, yielding not only a net benefit $\mathrm{N}_{\mathrm{B}}$, but also adding to his probability of harm. If harm occurs, it may be due to nature or to the victim's own behavior. In both cases it should be left with B. Consequently, A's expected payoff is 0 , while B is faced with expected harm $\left(\mathrm{p}_{0}+\mathrm{p}_{\mathrm{B}}\right) \mathrm{H}$.

In the lower left cell both nature and A contribute to the risk of harm. By engaging in careless behavior, A obtains a net benefit $\mathrm{N}_{\mathrm{A}}$. He also brings about an increase in expected harm equal to $\mathrm{p}_{\mathrm{A}} \mathrm{H}$. What fraction of harm should $e x$ post be apportioned to A such that he is faced with expected damages of $\mathrm{p}_{\mathrm{A}} \mathrm{H}$ ? Because the probability of harm is $\mathrm{p}_{0}+\mathrm{p}_{\mathrm{A}}, \mathrm{A}$ should pay a fraction $\mathrm{p}_{\mathrm{A}} /\left(\mathrm{p}_{0}+\mathrm{p}_{\mathrm{A}}\right)$ in damages if harm occurs:

$$
\mathrm{D}_{0 \mathrm{~A}}=\left[\mathrm{p}_{\mathrm{A}} /\left(\mathrm{p}_{0}+\mathrm{p}_{\mathrm{A}}\right)\right] \mathrm{H}
$$

By the same token, the fraction of harm that may be attributed to nature, $\mathrm{p}_{0} /\left(\mathrm{p}_{0}+\mathrm{p}_{\mathrm{A}}\right)$, is left with the victim. Hence, the remaining losses for $\mathrm{B}$ in case of harm are given by:

$$
\mathrm{L}_{0 \mathrm{~A}}=\left[\mathrm{p}_{0} /\left(\mathrm{p}_{0}+\mathrm{p}_{\mathrm{A}}\right)\right] \mathrm{H}
$$

On balance, expected payoffs are $\mathrm{N}_{\mathrm{A}}-\mathrm{p}_{\mathrm{A}} \mathrm{H}$ for injurer $\mathrm{A}$ and $-\mathrm{p}_{0} \mathrm{H}$ for victim $\mathrm{B}$.

\footnotetext{
${ }^{5}$ As noted before, it is not only the probability but also the amount of harm that may vary with the actors' behavior. If so, Table 1 should be set up in terms of expected harm $\mathrm{p}_{0} \mathrm{H}_{0}, \mathrm{p}_{0 \mathrm{~A}} \mathrm{H}_{0 \mathrm{~A}}>$ $\mathrm{p}_{0} \mathrm{H}_{0}, \mathrm{p}_{0 B} \mathrm{H}_{0 \mathrm{~B}}>\mathrm{p}_{0} \mathrm{H}_{0}, \mathrm{p}_{0 A B} \mathrm{H}_{0 \mathrm{AB}}=\mathrm{p}_{0} \mathrm{H}_{0}+\left(\mathrm{p}_{0 \mathrm{~A}} \mathrm{H}_{0 \mathrm{~A}}-\mathrm{p}_{0} \mathrm{H}_{0}\right)+\left(\mathrm{p}_{0 \mathrm{~B}} \mathrm{H}_{0 \mathrm{~B}}-\mathrm{p}_{0} \mathrm{H}_{0}\right)$. The proportional apportionment rule then should be applied in such a way that each actor expects to pay damages in proportion to the additional expected harm as a result of his careless behavior. For instance, if both $\mathrm{A}$ and $\mathrm{B}$ act carelessly, $\mathrm{A}$ 's expected damages, $\mathrm{P}_{0 \mathrm{AB}} \mathrm{D}_{0 \mathrm{AB}}$, should be in proportion to his addition to expected harm $\mathrm{p}_{0 \mathrm{AB}} \mathrm{H}_{0 \mathrm{AB}}-\mathrm{p}_{0 \mathrm{~B}} \mathrm{H}_{0 \mathrm{~B}}$. Thus: $\mathrm{D}_{0 \mathrm{AB}}=\mathrm{H}_{0 \mathrm{AB}}-\left(\mathrm{p}_{0 \mathrm{~B}} / \mathrm{p}_{0 \mathrm{AB}}\right) \mathrm{H}_{0 \mathrm{~B}}$. That is, $\mathrm{A}$ must pay the full harm $\mathrm{H}_{0 \mathrm{AB}}$ once it occurs (at probability $\mathrm{p}_{0 \mathrm{AB}}$ ), but is given a credit for that part of the harm that also would have occurred in the absence of his behavior. And so on. As notation would be heavily burdened without providing any real new insights to our line of argument, we will in the main text hold to the assumption that the amount of harm is invariant to the actors' behavior.
}

DOI: $10.2202 / 1555-5879.1340$ 
In the lower right cell both actors engage in careless behavior. The probability of harm is $\mathrm{p}_{0}+\mathrm{p}_{\mathrm{A}}+\mathrm{p}_{\mathrm{B}}$. In case of harm, A should pay the fraction that corresponds with his proportional contribution to the ultimate risk. For the damage payments by $\mathrm{A}$ in case of harm we thus have:

$$
\mathrm{D}_{0 \mathrm{AB}}=\left[\mathrm{p}_{\mathrm{A}} /\left(\mathrm{p}_{0}+\mathrm{p}_{\mathrm{A}}+\mathrm{p}_{\mathrm{B}}\right)\right] \mathrm{H}
$$

B should bear the remaining fraction, which consists of two elements, one corresponding with the contribution of nature and the other with his own contribution to the ultimate risk of harm. Hence, the losses that have to borne by $\mathrm{B}$ in case of harm are given by:

$$
\mathrm{L}_{0 \mathrm{AB}}=\left[\left(\mathrm{p}_{0}+\mathrm{p}_{\mathrm{B}}\right) /\left(\mathrm{p}_{0}+\mathrm{p}_{\mathrm{A}}+\mathrm{p}_{\mathrm{B}}\right)\right] \mathrm{H}
$$

On balance, the expected payoffs are $\mathrm{N}_{\mathrm{A}}-\mathrm{p}_{\mathrm{A}} \mathrm{H}$ for $\mathrm{A}$ and $\mathrm{N}_{\mathrm{B}}-\left(\mathrm{p}_{0}+\mathrm{p}_{B}\right) \mathrm{H}$ for $\mathrm{B}$.

Notice that in this additive case, expost the fractions of harm apportioned to $\mathrm{A}$ and $\mathrm{B}$ sum to one, i.e. total harm is fully divided between $\mathrm{A}$ and $\mathrm{B}$.

From Table 2 it can be easily seen that both $\mathrm{A}$ and $\mathrm{B}$ have a dominant strategy. A will act carelessly, if and only if $\mathrm{N}_{\mathrm{A}}>\mathrm{p}_{\mathrm{A}} \mathrm{H}$. B will engage in careless behavior, if and only if $\mathrm{N}_{\mathrm{B}}>\mathrm{p}_{\mathrm{B}} \mathrm{H}$. It is also immediately clear that the equilibrium that follows is efficient. Consequently, our rule for the ex post apportionment of liability leads ex ante to efficient decisions of both actors.

Table 2. Expected Payoffs in Additive Case

\begin{tabular}{|c|l|c|c|}
\hline \multicolumn{2}{|c|}{} & \multicolumn{2}{|c|}{ Victim B } \\
\cline { 3 - 4 } \multicolumn{2}{|c|}{} & Careful & Careless \\
\hline \multirow{3}{*}{ Injurer A } & Careful & $0,-p_{0} H$ & $0, N_{B}-\left(p_{0}+p_{B}\right) H$ \\
\cline { 2 - 4 } & Careless & $N_{A}-p_{A} H,-p_{0} H$ & $N_{A}-p_{A} H, N_{B}-\left(p_{0}+p_{B}\right) H$ \\
\hline
\end{tabular}

Since both actors have a dominant strategy, we can skip the precise chronological relationship between the acting of $\mathrm{A}$ and $\mathrm{B}$, as it is of no further consequence.

\subsection{RELATION TO THE LITERATURE}

The preceding analysis is closely related to the existing literature. Both Shavell (1985) and Young et al. (2004) discuss the setting where the harm, if any, is constant, say H. Only the probabilities of harm vary with the tortious acts that are undertaken.

The first case in Shavell (1985) and the central case in Young et al. (2004) involve causal uncertainty as a result of the interplay between one tortfeasor and nature. What is at stake then is just the left column of our Table 1. 
Additivity obtains in this simple case as a matter-of-course, as the excess risk of the act by $\mathrm{A}, \mathrm{p}_{0 \mathrm{~A}}-\mathrm{p}_{0}$, adds to the background risk from nature $\mathrm{p}_{0}$ to create the probability of harm $\mathrm{p}_{0 \mathrm{~A}}$.

In Shavell's (1985) second case causal uncertainty results from the interplay between two tortfeasors. Nature is assigned no role. The event that A causes an accident is moreover assumed to be mutually exclusive from the event that $\mathrm{B}$ causes an accident. In terms of our Table 1 , this boils down to: $\mathrm{p}_{0}=0, \mathrm{p}_{0 \mathrm{~A}}=$ $\mathrm{p}_{\mathrm{A}}, \mathrm{p}_{0 \mathrm{~B}}=\mathrm{p}_{\mathrm{B}}, \mathrm{p}_{0 \mathrm{AB}}=\mathrm{p}_{\mathrm{A}}+\mathrm{p}_{\mathrm{B}} \cdot{ }^{6}$ Hence, the case is arranged in such a manner that it satisfies the additivity criterion.

Shavell (1985) and Young et al. (2004) conclude that proportional liability yields socially efficient incentives. On reflection, this conclusion can be ascribed to the additivity of the risks of harm that is implicitly introduced in the structure of their cases.

\section{NON-ADDITIVITY}

We now turn to the non-additive case, i.e. $\mathrm{p}_{0 \mathrm{AB}} \neq \mathrm{p}_{0}+\mathrm{p}_{\mathrm{A}}+\mathrm{p}_{\mathrm{B}}$. Causal factors may reinforce one another, such that $\mathrm{p}_{0 \mathrm{AB}}>\mathrm{p}_{0}+\mathrm{p}_{\mathrm{A}}+\mathrm{p}_{\mathrm{B}}$. This will be called synergism. We speak of antagonism if $\mathrm{p}_{0 \mathrm{AB}}<\mathrm{p}_{0}+\mathrm{p}_{\mathrm{A}}+\mathrm{p}_{\mathrm{B}} \cdot{ }^{7} \mathrm{It}$ is helpful to write $\mathrm{p}_{0 \mathrm{AB}}=$ $\mathrm{p}_{0}+\mathrm{p}_{\mathrm{A}}+\mathrm{p}_{\mathrm{B}}+\alpha$. Synergism (antagonism) is obtained if $\alpha>0(\alpha<0)$. This case is summarized in Table 3.

Table 3. Probabilities of Harm in Non-Additive Case

\begin{tabular}{|c|c|c|c|}
\hline & \multicolumn{2}{|c|}{ Victim B } \\
\hline & & Careful & Careless \\
\hline \multirow{2}{*}{ Injurer A } & Careful & $\mathrm{p}_{0}$ & $P_{0 B}=p_{0}+p_{B}$ \\
\hline & Careless & $\mathrm{p}_{0 \mathrm{~A}}=\mathrm{p}_{0}+\mathrm{p}_{\mathrm{A}}$ & $p_{0 A B}=p_{0}+p_{A}+p_{B}+\alpha$ \\
\hline
\end{tabular}

We focus on the lower right cell of Table 3, since it is only this cell that differs from the additive case of Table 1 . In order to give $A$ the right incentive, he should be faced with the increase in risk that results from his behavior. Given B's behavior, A's carelessness results in an increase in the probability of harm from $\mathrm{p}_{0}+\mathrm{p}_{\mathrm{B}}$ to $\mathrm{p}_{0}+\mathrm{p}_{\mathrm{A}}+\mathrm{p}_{\mathrm{B}}+\alpha$. Consequently, $\mathrm{A}$ should pay damages equal to:

$$
\mathrm{D}_{0 \mathrm{AB}}=\left[\left(\mathrm{p}_{\mathrm{A}}+\alpha\right) /\left(\mathrm{p}_{0}+\mathrm{p}_{\mathrm{A}}+\mathrm{p}_{\mathrm{B}}+\alpha\right)\right] \mathrm{H}
$$

\footnotetext{
${ }^{6}$ Compare with. Shavell (1985:599-600), in particular note 25.

7 The terms synergism and antagonism are taken from Rothman et al. (2008).
}

DOI: $10.2202 / 1555-5879.1340$ 
Given A's behavior, B's carelessness results in an increase in the probability of harm from $\mathrm{p}_{0}+\mathrm{p}_{\mathrm{A}}$ to $\mathrm{p}_{0}+\mathrm{p}_{\mathrm{A}}+\mathrm{p}_{\mathrm{B}}+\alpha$. From that perspective, $\mathrm{B}$ should bear the fraction $\left(\mathrm{p}_{\mathrm{B}}+\alpha\right) /\left(\mathrm{p}_{0}+\mathrm{p}_{\mathrm{A}}+\mathrm{p}_{\mathrm{B}}+\alpha\right)$ of harm. Furthermore, the harm that can be attributed to natural causes should be left with the victim. In total, B thus should bear losses equal to:

$$
\mathrm{L}_{0 \mathrm{AB}}=\left[\left(\mathrm{p}_{0}+\mathrm{p}_{\mathrm{B}}+\alpha\right) /\left(\mathrm{p}_{0}+\mathrm{p}_{\mathrm{A}}+\mathrm{p}_{\mathrm{B}}+\alpha\right)\right] \mathrm{H}
$$

Notice that the sum of the fractions apportioned to $\mathrm{A}$ and $\mathrm{B}$ in this way is equal to $\left(\mathrm{p}_{0}+\mathrm{p}_{\mathrm{A}}+\mathrm{p}_{B}+2 \alpha\right) /\left(\mathrm{p}_{0}+\mathrm{p}_{\mathrm{A}}+\mathrm{p}_{B}+\alpha\right)$, which can be rewritten into $1+$ $\alpha /\left(p_{0}+p_{A}+p_{B}+\alpha\right)$. Consequently, the sum of the fractions of harm apportioned to $\mathrm{A}$ and $\mathrm{B}$ is not equal to 1 , once $\alpha \neq 0.8$ In case of synergism (antagonism) the sum will be larger (smaller) than 1. Stated otherwise, in compensation of his harm victim $B$ should receive less (more) than the amount of damages paid by injurer A. Thus a third party is needed (say, the government or an equalization fund) which can collect (make up) the difference.

Table 4 presents the expected payoffs for the non-additive case. It immediately follows that it depends on the specific set of parameters, most notably on the value of $\alpha$, whether A and B have a dominant strategy. For that reason, and because a third party may collect or pay part of the damages, the specific topological and chronological relationship between the acting of $\mathrm{A}$ and $\mathrm{B}$ becomes of relevance.

Table 4. Expected Payoffs in Non-Additive Case

\begin{tabular}{|c||c|c|c|}
\hline \multicolumn{2}{|c|}{} & \multicolumn{2}{c|}{ Victim B } \\
\cline { 3 - 4 } \multicolumn{2}{|c|}{} & Careful & Careless \\
\hline \multirow{2}{*}{ Injurer $A$} & Careful & $0,-\mathrm{p}_{0} \mathrm{H}$ & $0, \mathrm{~N}_{\mathrm{B}}-\left(\mathrm{p}_{0}+\mathrm{p}_{B}\right) \mathrm{H}$ \\
\cline { 2 - 4 } & Careless & $\mathrm{N}_{\mathrm{A}}-\mathrm{p}_{\mathrm{A}} \mathrm{H},-\mathrm{p}_{0} \mathrm{H}$ & $\mathrm{N}_{\mathrm{A}}-\left(\mathrm{p}_{\mathrm{A}}+\alpha\right) \mathrm{H}, \mathrm{N}_{\mathrm{B}}-\left(\mathrm{p}_{0}+\mathrm{p}_{\mathrm{B}}+\alpha\right) \mathrm{H}$ \\
\hline
\end{tabular}

\subsection{SYNERGISM, WITH INDEPENDENT AND SIMULTANEOUS ACTING}

In Table 5 we present the Nash equilibrium outcome(s), under the assumption that the actors act independently and simultaneously.

\footnotetext{
8 The conclusion that damages may need to be unequal to total harm in order to provide efficient incentives to all parties can also be found in Miceli and Segerson (1991) and Young et al. (2007).
} 
Additive and Non-Additive Risk Factors in Multiple Causation / 527

Table 5. Equilibrium Outcome(s) in Case of Synergism

\begin{tabular}{|c|c|c|c|}
\hline & $\mathrm{N}_{\mathrm{B}}<\mathrm{p}_{\mathrm{B}} \mathrm{H}$ & $\mathrm{p}_{\mathrm{B}} \mathrm{H}<\mathrm{N}_{\mathrm{B}}<\left(\mathrm{p}_{\mathrm{B}}+\alpha\right) \mathrm{H}$ & $\mathrm{N}_{\mathrm{B}}>\left(\mathrm{p}_{\mathrm{B}}+\alpha\right) \mathrm{H}$ \\
\hline $\mathrm{N}_{\mathrm{A}}<\mathrm{p}_{\mathrm{A}} \mathrm{H}$ & $\begin{array}{l}\text { A careful and } \\
\text { B careful }\end{array}$ & $\begin{array}{l}\text { A careful and } \\
\text { B careless }\end{array}$ & $\begin{array}{l}\text { A careful and } \\
\text { B careless }\end{array}$ \\
\hline $\mathrm{p}_{\mathrm{A}} \mathrm{H}<\mathrm{N}_{\mathrm{A}}<\left(\mathrm{p}_{\mathrm{A}}+\mathrm{\alpha}\right) \mathrm{H}$ & $\begin{array}{l}\text { A careless and } \\
\text { B careful }\end{array}$ & $\begin{array}{l}\text { 1. A careful and } \\
\text { B careless } \\
\text { 2. A careless and } \\
\text { B careful }\end{array}$ & $\begin{array}{l}\text { A careful and } \\
\text { B careless }\end{array}$ \\
\hline$N_{A}>\left(p_{A}+\alpha\right) H$ & $\begin{array}{l}\text { A careless } \\
\text { and B careful }\end{array}$ & $\begin{array}{l}\text { A careless and } \\
\text { B careful }\end{array}$ & $\begin{array}{l}\text { A careless and } \\
\text { B careless }\end{array}$ \\
\hline
\end{tabular}

In the case of synergism, $\alpha>0$, there are nine parameter configurations of interest. Each of these has an efficient equilibrium outcome. For eight parameter configurations, there is just one equilibrium, which can easily be shown to be the efficient outcome, given the specific parameter configuration. For one parameter configuration, we have two equilibria, one of which is the efficient outcome.

Stated differently, only cases in the centre cell of Table 5 can possibly, but not necessarily, lead to an inefficient outcome. For given values of $\mathrm{N}_{\mathrm{A}}, \mathrm{N}_{\mathrm{B}}, \mathrm{p}_{\mathrm{A}}, \mathrm{p}_{\mathrm{B}}$ and $\mathrm{H}$, it depends on $\alpha$ whether a case falls within the reach of the center cell. More precisely, for a case to fall within the reach of the center cell the parameter configuration should be such that $\alpha>\min \left\{\mathrm{N}_{\mathrm{A}} / \mathrm{H}-\mathrm{p}_{\mathrm{A}}, \mathrm{N}_{\mathrm{B}} / \mathrm{H}-\mathrm{p}_{\mathrm{B}}\right\}>0$. Thus, if $\alpha$ is low enough, the proposed rule will always yield an efficient outcome.

\subsection{SYNERGISM, WITH ACTORS ACTING IN CONCERT ${ }^{9}$}

Turning to topology, we now address the case where the two actors act in concert. Is there any room for the two actors to improve on their expected payoffs, given the proportional apportionment rule? Two opportunities present themselves.

First, we have the set of parameter values discussed in Table 5 where the equilibrium is not unique. In concert the actors will choose the one equilibrium with the largest combined expected payoff, which is the efficient result.

Second, we must consider any parameter configuration where the lower right cell of Table 4 is the Nash equilibrium. This is the only unique and efficient equilibrium where the two actors can improve on their combined payoff by saving on the excess damage payment to the third party. If the size of the synergism effect is large enough, it may prove to be in the actors' interest to

\footnotetext{
${ }^{9}$ A setting where the injurer and victim act in concert may seem somewhat odd. The analysis can, however, almost directly be applied to a case with two potential injurers. A slightly different interpretation of the role of actor B suffices.
}

DOI: $10.2202 / 1555-5879.1340$ 
deviate from the equilibrium as it would result under independent and simultaneous acting, and thus to deviate from efficiency.

In summary: proportional liability does not always provide efficient incentives when tortfeasors act in concert. Joint liability would be the better apportionment rule for this kind of cases. ${ }^{10}$

\subsection{Synergism, with A AND B Acting SEQuentially}

Finally, we address the case where $\mathrm{A}$ and $\mathrm{B}$ act sequentially. We assume that the act of A precedes the act by B. Once again, we want to study the effects from our proportional apportionment rule. However, matters are complicated because we may have two different interpretations of the rule. One version holds that each actor takes the situation as he finds it, and should not be expected to anticipate (and held liable for) any act by another actor following his own careless behavior. The other version is less forgiving and holds any actor liable for all additional damages that could reasonably be anticipated to emerge from his careless behavior, either directly or indirectly.

The second version once again yields the apportionment rule as before. First step in the analysis is then to transform the payoff matrix of Table 4 in a decision tree, with A's decision to act preceding the decision by B. Next step is to consider if there are any circumstances under which the equilibrium might be different from independent and simultaneous acting. This will not occur if A had a dominant strategy nor if $\mathrm{B}$ had a dominant strategy, which is the case in 8 out of the 9 parameter configurations that were distinguished in Table 5. These are the configurations with a unique and efficient equilibrium. What remains is the parameter configuration such that $\mathrm{p}_{\mathrm{A}} \mathrm{H}<\mathrm{N}_{\mathrm{A}}<\left(\mathrm{p}_{\mathrm{A}}+\alpha\right) \mathrm{H}$ and $\mathrm{p}_{\mathrm{B}} \mathrm{H}<\mathrm{N}_{\mathrm{B}}<$ $\left(p_{B}+\alpha\right) H$, where we had two Nash equilibria: either A acts carelessly and B acts with care, or vice versa. When B follows behind, actor A can steer B towards the one of these two equilibria that is most favorable for himself. But there is no guarantee that this outcome is also the efficient one of the two equilibria.

The first version of the proportional liability rule works out somewhat differently. As the first actor, A, is not expected to anticipate any careless behavior following his own careless behavior, he is only held liable for the direct additional expected harm that may result from his act: $\mathrm{p}_{A} \mathrm{H}$. Damage payments by $A$ then are always determined by the application of apportionment rule (3), irrespective of the behavior by B. B, however, follows upon A. The additional expected harm of B's careless behavior is either $\mathrm{p}_{B} \mathrm{H}$ when $A$ acted with care, or $\left(\mathrm{p}_{B}+\alpha\right) H$ when $A$ was the first to act carelessly. The

\footnotetext{
${ }^{10}$ If the actors work in concert and maximize the combined expected payoff, it is efficient to have the full harm (no more, no less) being internalized by the combined actors.
} 
Additive and Non-Additive Risk Factors in Multiple Causation / 529

losses that should be borne by B are either set through apportionment rule (4) or (6), depending on whether A preceded his careless behavior. ${ }^{11}$ Because the new version of the apportionment rule is less severe for A, it might affect A's decision. But it can only effectively do so within the range of parameter values such that $\mathrm{p}_{A} \mathrm{H}<\mathrm{N}_{\mathrm{A}}<\left(\mathrm{p}_{\mathrm{A}}+\alpha\right) \mathrm{H}^{12}$ and such that $\mathrm{N}_{\mathrm{B}}>\left(\mathrm{p}_{B}+\alpha\right) \mathrm{H} \cdot{ }^{13}$ In this one of the 9 possible parameter configurations A will decide differently from the situation of independent and simultaneous acting studied in Table 5. That is, A will decide to act carelessly, leading to an inefficient result.

\subsection{ANTAGONISM}

Having studied synergism in some depth, we can now be short on the subject of antagonism. Application of our proportional apportionment rule yields expected damage payments that do not fully compensate victim $\mathrm{B}$ for the additional harm for which the combined actors can be deemed responsible. We can imagine the state making up the deficit from the same fund that has been filled by the excess payments in synergistic cases. Given this essential difference, the general conclusions of our earlier analysis remain valid.

\subsection{RELATION TO THE LITERATURE}

The element of non-additivity remains somewhat implicit in the literature on joint causation. But it is definitely there.

Kornhauser \& Revesz (1989) discuss a setting in which several manufacturers dump their wastes at a single landfill. At some time in the future, these wastes may leak into the environment and cause serious damage to the environment. The harm can be measured by the cost of cleaning up the landfill and the surrounding area affected by the release. That cost is as a matter-of-course assumed to be convex in the amounts of waste dumped. But it is precisely this convexity that introduces synergism in the setting, as total harm is assumed to increase more than proportionally by every additional dumping of waste. Provided the manufacturers act independently and simultaneously, proportional apportionment of the harm according to equations (1) and (5) might be a useful

\footnotetext{
${ }^{11}$ Notice that the sum of the fractions apportioned to $\mathrm{A}$ and $\mathrm{B}$ now always equals 1, irrespective of whether $\mathrm{A}$ acts with or without care. Hence, there are no excess payments to a third party.

${ }^{12}$ For if $\mathrm{N}_{\mathrm{A}}<\mathrm{p}_{\mathrm{A}} \mathrm{H}$, A will act with care anyway; and if $\mathrm{N}_{\mathrm{A}}>\left(\mathrm{p}_{\mathrm{A}}+\alpha\right) \mathrm{H}$ A will definitely act without care. A's decision will not change as a result of the less severe liability rule.

${ }^{13}$ For if $\mathrm{N}_{\mathrm{B}}<\left(\mathrm{p}_{\mathrm{B}}+\alpha\right) \mathrm{H}, \mathrm{B}$ will decide not to act carelessly if A would choose to do so. But if $\mathrm{B}$ decides not to act carelessly, then A cannot profit from the less severe liability rule. So, A's decision will not change.
}

DOI: $10.2202 / 1555-5879.1340$ 
alternative liability rule to the one proposed by Kornhauser \& Revesz themselves, which requires that the court calculates the efficient levels of care.

Miceli \& Segerson (1991) consider a situation in which two actors, acting independently, contribute to the probability that an accident will occur. In a mathematical appendix they show within a most general setting how a liability rule that takes account of both additional expected harm due to the activity of an actor and the change in the net benefits of the other actor may provide incentives for marginal as well as infra-marginal efficiency. The complexity of this rule, however, would seem to defy any practical application by the courts. But the authors also provide a somewhat simpler illustration in the main text of their article. Harm is taken to be constant at 750 when an accident occurs, but the probability of harm which is only 0.08 if one actor is active, rises to 0.20 if both actors are active. Of course, this tort case hinges on synergism. And it can indeed be efficiently handled with proportional apportionment, as pointed out by Miceli \& Segerson themselves.

That brings us finally to Young et al. (2007). Starting from the framework of Figure 1 above they introduce a second actor E, who through the working of nature E' (with probability r) may contribute to the risk of harm. When the act by $\mathrm{E}$ takes the place of $\mathrm{C}$ in the framework, the acts of $\mathrm{A}$ and $\mathrm{E}$ work in parallel. Either can lead to the harm, irrespective of the other. When the act by E takes the place of A', the situation is one where the acts by A and E work in series. Both are necessary elements in a sufficient cause, but there may be another sufficient cause initiated by B. The act by E may also take the place of B. E's act is then a necessary element in all sufficient causes, only one of which is initiated by A. Table 6 summarizes the probabilities of harm, assuming that the various probabilities at stake work statistically independent from one another.

When presented like this, it is readily seen that all three topological scenarios studied by Young et al. are characterized by non-additivity. The first case where the torts work in parallel is one of antagonism, the other two are cases of synergism. It immediately follows from the analysis above that application of our proportional apportionment rule (1) and (5) will yield efficient incentives when the potential tortfeasors act independently and simultaneously, confirming the conclusion by Young et al. on that point. Their conclusion for sequentially acting tortfeasors is not correct, however. ${ }^{14}$ They apply the version of the proportional apportionment rule, where the first actor is only held liable for the direct additional expected harm that results from his act. Our analysis has shown that that version of the rule may lead to inefficient results.

14 The relevant conclusions by Young et al. (2007:123) are contained in their Table 1. 
Additive and Non-Additive Risk Factors in Multiple Causation / 531

Table 6. Probabilities of Harm

\begin{tabular}{|c|c|c|c|}
\hline \multirow{2}{*}{\multicolumn{2}{|c|}{ i. A and $E$ work in parallel }} & \multicolumn{2}{|r|}{ E acts } \\
\hline & & No & Yes \\
\hline \multirow{2}{*}{$A$ acts } & No & 0 & $\mathrm{rp}$ \\
\hline & Yes & $\mathrm{qp}$ & {$[r+(1-r) q] p=[q+(1-q) r] p$} \\
\hline \multirow{2}{*}{\multicolumn{2}{|c|}{ ii. A and $E$ work in series }} & \multicolumn{2}{|r|}{$\mathrm{E}$ acts } \\
\hline & & No & Yes \\
\hline \multirow{2}{*}{ A acts } & No & $(1-\pi) p$ & $(1-\pi) p$ \\
\hline & Yes & $(1-\pi) p$ & {$[(1-\pi)+\pi r] p$} \\
\hline \multirow{2}{*}{\multicolumn{2}{|c|}{$\begin{array}{l}\text { iii. E is a necessary element } \\
\text { in all sufficient causes }\end{array}$}} & \multicolumn{2}{|r|}{ E acts } \\
\hline & & No & Yes \\
\hline \multirow{2}{*}{ A acts } & No & 0 & $(1-\pi) r$ \\
\hline & Yes & 0 & {$[(1-\pi)+\pi q] r$} \\
\hline
\end{tabular}

\section{APPLICATIONS}

In this section we demonstrate how the theoretical framework may be applied in practice. For that purpose we discuss four cases from English jurisprudence so as to cover the various set-ups that were distinguished above. Fairchild $v$. Glenhaven Funeral Services Ltd is a case of causal uncertainty, while Holtby $v$. Brigham \& Cowan Ltd is characterized by joint causation, both with additive risks. Non-additive risks appear at Badger $v$. The Ministry of Defense, a case of causal uncertainty, and at Rouse $v$. Squires, a case of joint causation. Moreover, in Badger $v$. The Ministry of Defense the relevant actors were acting simultaneously, while they were acting sequentially in Rouse $v$. Squires.

\subsection{FAIRCHILD V. GLENHAVEN FUNERAL SERVICES LTD., [2002] 3 ALL ER 305}

During his working life Fairchild worked for two different asbestos processing employers, A and B. As both employers breached the duty to take sufficient preventive measures, Fairchild had to inhale substantial quantities of dust containing asbestos fiber. This caused him to suffer a mesothelioma, of which he died in 1996 at age 60.

His widow filed a claim. From medical science it was accepted that the risk of developing a mesothelioma increases in proportion to the quantity of asbestos dust and fibers inhaled. But the condition may be caused by many fibers, or a few fibers, or a single fiber. None of these possibilities is more probable than any other, and the condition once caused is not aggravated by further exposure. Any cause of Fairchild's mesothelioma other than the inhalation of asbestos dust at work could be effectively discounted. But there was no way of

DOI: $10.2202 / 1555-5879.1340$ 
identifying ex post, even on a balance of probabilities, whether the mesothelioma was the result of inhaling asbestos dust during his employment by employer A, or by employer B, or by both employers $\mathrm{A}$ and $\mathrm{B}$. For that reason the claim was dismissed by both the trial judge and the Court of Appeal.

The House of Lords reconsidered the case in 2002. It was argued that, in certain special circumstances, the court could depart from the usual 'but for' test of causal connection. In the circumstances of the case it would be just to accept a lesser degree of causal connection as sufficient, namely that each employer's breach of duty had materially contributed to causing Fairchild's disease by materially increasing the risk of the disease being contracted. The widow should be allowed to recover full compensation against either A or B, leaving it to A and $\mathrm{B}$ to seek restitution against each other in the ordinary way.

To analyze this case in terms of our theoretical framework, we make an $e x$ ante reconstruction. Let $\mathrm{p}$ be the risk of developing a mesothelioma being exposed to asbestos dust during a year. And let $t_{A}$ and $t_{B}$ be the number of years Fairchild worked for employers $\mathrm{A}$ and $\mathrm{B}$, respectively. ${ }^{15}$ If there is no other cause of a mesothelioma than the inhalation of asbestos dust at work and if the risk of developing a mesothelioma increases in proportion to the quantity of asbestos dust and fibers inhaled, the probability can be taken to be proportional to the length of the exposure to asbestos, that is the length of the employment period if the employer is not taking adequate preventive measures. See Table 7. It can moreover be taken for granted that the harm, if it occurs, is always the same, say H. Clearly this case is characterized by additivity of risks.

Table 7. Probabilities of Harm in Fairchild v. Glenhaven Funeral Services Ltd.

\begin{tabular}{|c|l|c|c|}
\hline \multicolumn{2}{|c|}{} & \multicolumn{2}{c|}{ Employer B } \\
\cline { 3 - 4 } \multicolumn{2}{|c|}{} & $\begin{array}{c}\text { No asbestos } \\
\text { exposure }\end{array}$ & $\begin{array}{c}\text { Asbestos } \\
\text { exposure }\end{array}$ \\
\hline \multirow{2}{*}{ Employer A } & No asbestos exposure & 0 & $t_{B} p$ \\
\cline { 2 - 4 } & Asbestos exposure & $t_{A} p$ & $\left(t_{A}+t_{B}\right) p$ \\
\hline
\end{tabular}

What fraction of harm should expost be apportioned to each actor in order to give him ex ante the right incentives? We focus on the lower right cell, as it is the situation that in fact obtained in the Fairchild case.

Employer $A$ caused an increase in the probability of harm from $t_{B} p$ to $\left(t_{A}+t_{B}\right) p$. Hence, employer A's share in the probability of harm is $t_{A} /\left(t_{A}+t_{B}\right)$. From an efficiency point of view this share of harm should be apportioned to A.

\footnotetext{
15 If the intensity of asbestos exposure during the employment spells differed, $t_{A}$ and $t_{B}$ should be expressed in standardized terms.
} 
Employer B caused an increase in the probability of harm from $t_{A} p$ to $\left(t_{A}+t_{B}\right) p$. $B$ should be apportioned a share of harm equal to $t_{B} /\left(t_{A}+t_{B}\right)$. Thus, the shares of $\mathrm{A}$ and $\mathrm{B}$ should be proportional to the length of the employment period, in accordance with apportionment rule (3).

Seen from this perspective, the House of Lords did a good job in accepting the material contribution to the risk of harm as the basis for causation, albeit only in this special case. Instead of holding the two employers jointly liable with the option to seek contribution from each other, the Lords might as well have decided on proportional liability in the first place. But of course the practical difference may be quite small. ${ }^{16}$

\subsection{HoltBy V. BRIGHAM \& COWAN LTD., [2000] 3 ALL ER 421}

The second case differs in one important aspect from the first. Holtby, too, was exposed to asbestos dust during his working life. For about half the period, namely some 12 years, he was employed by A. For the remainder of the period he was working for several other employers in much shorter contracts. Instead of a mesothelioma, however, Holtby developed asbestosis.

Medical experts pointed out that all exposures to asbestos contribute to the development of asbestosis. Wherever the inhaled dust comes to rest in the lungs, there is slow growth of fibrous tissue, gradually strangling the essential air cells. It is only when the fibrosis progresses to the extent of obliterating the large reserve capacity of the lungs, that undue shortness of breath results. From that point on the disease progresses with noticeable effect, since it is encroaching on the remaining sound tissue of the lungs.

\footnotetext{
16 The House of Lords explicitly accepted proportional liability in a follow-up case, Barker $v$. Corus (UK) Ltd., [2006] 3 All ER 785. Barker, too, died of an asbestos-related mesothelioma. But he had three material exposures to asbestos: the first while working for a company which had since become insolvent, the second while working for a company which later had been absorbed by Corus, and the third while being self-employed. In line with the Fairchild judgment, the trial judge and the Court of Appeal decided that Barker's widow might sue any employer for full compensation, despite being unable to prove which exposure had caused the disease, but subject to a $20 \%$ reduction for the victim's contributory negligence while being self-employed. The House of Lords, however, allowed the appeal, remitting the case for redetermination of damages. The extent of the liability of each defendant in a case where the Fairchild exception applied should be commensurate with the degree of risk for which that defendant was responsible.

But proportional liability was not there for long to stay. It was overturned by the Compensation Act 2006, establishing joint and several liability as the general rule for mesothelioma cases. The rule does not prevent an actor that is held liable to seek contribution from other actors. The court then shall have regard to the relative lengths of the periods of exposure for which each actor was responsible.
}

DOI: $10.2202 / 1555-5879.1340$ 
The victim brought an action against A. At trial, the employer was held liable because of breach of duty, but only for the damage that he had caused. As Holtby's condition would have been less severe if he had only sustained asbestos exposure while working for A, the judge reduced damages by $25 \%$. The Court of Appeal reconsidered the cumulative effect of the exposure and decided that the correct approach would be to divide responsibility on a time exposure basis. A thus should have been made liable only to $50 \%$. However, as the trial judge was not to be criticized for erring on the side of generosity to Holtby, the appeal was dismissed.

We again give an ex ante reconstruction. Let $\mathrm{p}$ be the risk of developing asbestosis. Let $\mathrm{h}$ be the harm to the lungs for each year of asbestos exposure. And let $t_{A}$ and $t_{B}$ be the number of years Holtby worked for employer $A$ and for other employers. Because in this case it is not the probability but the amount of harm that varies, Table 8 presents the expected harm. ${ }^{17}$ Note that the case is characterized by joint causation and by additivity.

Table 8. Expected Harm in Holtby v. Brigham \& Cowan Ltd.

\begin{tabular}{|l|l|c|c|}
\hline \multicolumn{2}{|c|}{} & \multicolumn{2}{|c|}{ Other employers } \\
\cline { 3 - 4 } \multicolumn{2}{|c|}{} & $\begin{array}{c}\text { No asbestos } \\
\text { exposure }\end{array}$ & $\begin{array}{c}\text { Asbestos } \\
\text { exposure }\end{array}$ \\
\hline \multirow{3}{*}{ Employer A } & No asbestos exposure & 0 & pht $_{B}$ \\
\cline { 2 - 4 } & Asbestos exposure & pht $_{A}$ & ph $\left(\mathrm{t}_{\mathrm{A}}+\mathrm{t}_{\mathrm{B}}\right)$ \\
\hline
\end{tabular}

We can now calculate what fraction of harm should expost be apportioned to each actor in order to give proper incentives ex ante. In the lower right cell, employer $A$ caused an increase in expected harm from pht $t_{B}$ to $p h\left(t_{A}+t_{B}\right)$. Hence, employer A's share in expected harm is $t_{A} /\left(t_{A}+t_{B}\right)$. From an efficiency point of view this share of harm should be apportioned to A. The other employers caused an increase in expected harm from $\mathrm{pht}_{\mathrm{A}}$ to $\mathrm{ph}\left(\mathrm{t}_{\mathrm{A}}+\mathrm{t}_{\mathrm{B}}\right)$. They should be apportioned a share of harm equal to $t_{B} /\left(t_{A}+t_{B}\right)$. Thus, the shares of the employers should be proportional to the length of the employment period, in accordance with apportionment rule (3).

Seen from this perspective, the Court of Appeal did a good job in accepting proportional liability. A liability share of $75 \%$ for A, however, was indeed too large, given his $50 \%$ time share of employment and exposure. Whether this will yield inefficient incentives after all, depends on at least two additional considerations. Will Holtby and his co-victims succeed in obtaining compensatory damages from all their employers, both on long-term and on

\footnotetext{
${ }^{17}$ Compare with note 5 .
} 
short-term contracts? And if they don't succeed, have all the employers a similar mix of long-term and short-term employment contracts?

\subsection{BADGER V. THE MINISTRY OF DEFENSE, [2006] 3 ALL ER 173}

The third case is once again an asbestos affair. Badger died of lung cancer in 2002 at the age of 63 years. Between 1954 and 1987 he had been employed by the Ministry of Defense. In the course of his work, he was exposed to asbestos dust and fibers. But he also smoked over the entire period of his employment and continued to do so until the beginning of 2002.

The case was brought before the Queen's Bench of the High Court of Justice. The Ministry of Defense admitted primary liability, but it contended that the claim of his widow should be reduced on account of Badger's contributory negligence. The court considered that a reasonably prudent person would have stopped smoking by the mid-1970s, so the victim's behavior was indeed blameworthy, but only during the second part of his life. The reduction in damages attributable to Badger's continuing to smoke after he should have stopped, was set at $20 \%$.

Table 9 shows the probabilities of harm as presented in the Court's judgment, based on scientific expertise. A never-smoker with no history of asbestos exposure has a $0.3 \%$ risk of getting lung cancer at age 63 , while the same risk for a smoker of 20 cigarettes a day is $3 \%$. Furthermore, it is estimated that Badger's exposure to asbestos gave rise to a multiplier of 5 .

Table 9. Probabilities of Harm in Badger v. The Ministry of Defense

\begin{tabular}{|l|l|c|c|}
\hline \multicolumn{2}{|c|}{} & \multicolumn{2}{|c|}{ Badger } \\
\cline { 3 - 4 } \multicolumn{2}{|c|}{ Ministry } & No smoking & Smoking \\
\cline { 2 - 4 } & Asbestos exposure & $0.3 \%$ & $3.0 \%$ \\
\hline \multirow{2}{*}{} & & $1.5 \%$ & $15.0 \%$ \\
\hline
\end{tabular}

Note that this is a case of causal uncertainty with synergism. The actual situation is represented by the lower right cell. Following our apportionment rules (5) and (6), the Ministry should pay $(15.0-3.0) / 15.0=80 \%$ of harm in damages, while Badger's widow should bear $(15.0-1.5+0.3) / 15.0=95 \%$ in losses.

But this calculation is somewhat rash, as it fails to appreciate the public awareness of the adverse health effects of smoking, which was nearly absent in the 1950s and since then only gradually gained momentum. Badger should have known the facts by the mid-1970s. If he had stopped smoking at age 40, his risk of developing lung cancer at age 63 would have been $1.3 \%$. This seems to be a more proper figure to start from than the $0.3 \%$. Table 10 presents the

DOI: $10.2202 / 1555-5879.1340$ 
adjusted probabilities of harm, holding on to the multiplier of 5 for the impact of the asbestos exposure.

Table 10. Probabilities of Harm in Badger v. The Ministry of Defense (adjusted)

\begin{tabular}{|c|c|c|c|}
\hline & \multicolumn{2}{|c|}{ Badger } \\
\hline & & Stop smoking & Continue smoking \\
\hline \multirow{2}{*}{ Ministry } & No asbestos exposure & $1.3 \%$ & $3.0 \%$ \\
\hline & Asbestos exposure & $6.5 \%$ & $15.0 \%$ \\
\hline
\end{tabular}

Applying our apportionment rule to the lower right cell, it follows that the Ministry should pay $(15.0-3.0) / 15.0=80 \%$ of harm in damages. Badger's widow, however, should bear $(15.0-6.5+1.3) / 15.0=65 \%$ in losses. That would $e x$ ante give efficient incentives in similar cases.

Seen from this perspective, the High Court of Justice provided efficient incentives by ordering a $20 \%$ reduction in the damages to be paid by the Ministry of Defense. However, the fact that the Court came up with that exact figure was rather a coincidence, although the reasoning behind the judgment definitely contained some elements that are relevant from an efficiency point of view. The Court, moreover, did not accept the principle of a proportional apportionment of harm in this case of causal uncertainty. Its judgment also was not adequate insofar as it ordered a fraction of $80 \%$ of harm to be paid to Badger's widow; $35 \%$ would have been sufficient.

\subsection{ROUSE V. SQUIRES AND OTHERS, [1973] 2 ALL ER 903}

Our fourth case is a traffic accident. At about 10.30 p.m. on a frosty night A was driving an articulated lorry when, because of his negligence, it skidded, 'jack-knifed,' and ended up blocking two lanes of the motorway. Some five to ten minutes after the original accident, $\mathrm{B}$ arrived on the scene driving his employers' lorry at a fast speed. He failed to stop in time, and caused the death of Rouse who was helping at the scene.

Rouse's widow obtained damages against $B$ in respect of his negligent driving. In third party proceedings, B claimed contribution from $A$ and his employers in respect of A's negligence. The trial judge dismissed the claim, holding that B was wholly to blame for the accident. If B had kept a proper look-out he would have had sufficient time to take avoiding action. According to the Court of Appeal, however, A had contributed to Rouse's death. If a driver so negligently manages his vehicle as to cause it to obstruct the highway and constitute a danger to other road users, then his negligence may be held to contribute to the causation of an accident that follows upon the obstruction. In the circumstances $25 \%$ of the blame should be attributed to A and $75 \%$ to B. 
We make an ex ante reconstruction. If A drives with sufficient care given the circumstances, his lorry will not skid and the probability of an accident will be (almost) nil. If B keeps a proper look-out, he will in general have sufficient time to anticipate and react to any misbehavior from other travelers on the road. So, the probability of harm will also be (almost) nil. It is only when both A and B don't employ sufficient care, that there is a real probability of a traffic accident. For our present purpose, it will suffice to represent this probability by p. See Table 11.

Table 11. Probabilities of Harm in Rouse v. Squires

\begin{tabular}{|l|l|c|c|}
\hline \multicolumn{2}{|c|}{} & \multicolumn{2}{c|}{ Driver B } \\
\cline { 3 - 4 } \multicolumn{2}{|c|}{} & Careful & Careless \\
\hline \multirow{2}{*}{ Driver A } & Careful & 0 & 0 \\
\cline { 2 - 4 } & Careless & 0 & $\mathrm{p}$ \\
\hline
\end{tabular}

Notice that this is a case of joint causation with synergism, but also with sequential acting. Following the argument of Section 4 we should apply the proportional apportionment rule (5) to obtain efficient incentives. That is, driver A should pay $(\mathrm{p}-0) / \mathrm{p}=100 \%$ of harm in damages, while driver $\mathrm{B}$ should also bear a share of $(p-0) / p=100 \%$. Figure 2 shows the resulting decision tree, with $\mathrm{N}_{\mathrm{A}}$ and $\mathrm{N}_{\mathrm{B}}$ denoting the net benefits (relative to acting with care) from careless behavior. It rather easily follows that the incentives are efficient for almost all parameter settings. ${ }^{18}$

Figure 2. Decision Tree in Rouse v. Squires

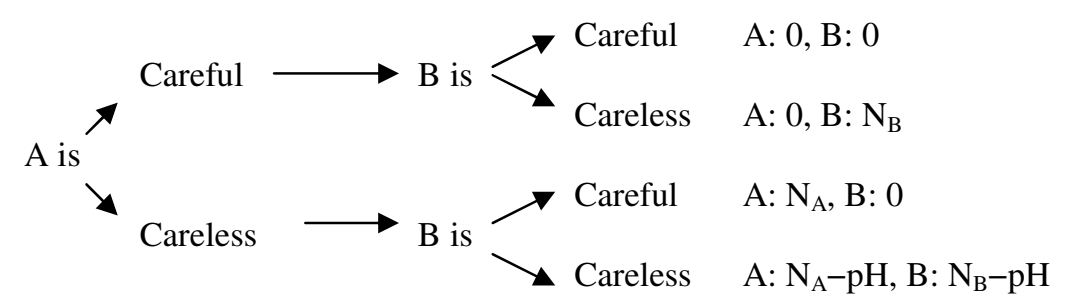

\footnotetext{
18 That is, only if both $\mathrm{N}_{\mathrm{A}}<\mathrm{pH}$ and $\mathrm{N}_{\mathrm{B}}<\mathrm{pH}$ may an inefficient outcome result. In that parameter configuration it is welfare enhancing if only one driver would be careful, thus avoiding any accident, but still realizing a net benefit $\mathrm{N}_{\mathrm{A}}$ or $\mathrm{N}_{\mathrm{B}}$. If $\mathrm{A}$ acts first, he will choose to be the one acting carelessly, thus realizing a net benefit $\mathrm{N}_{A}$. This will be inefficient if $\mathrm{N}_{\mathrm{B}}$ is the larger net benefit of the two.
}

DOI: $10.2202 / 1555-5879.1340$ 
Seen from this perspective, the Court of Appeal did not provide efficient incentives by attributing $25 \%$ of the blame to $\mathrm{A}$ and $75 \%$ to $\mathrm{B}$. Both were equally fully to blame. ${ }^{19}$

\section{CONCLUSION}

In this paper we considered the efficiency of tort law in the case of multiple causation. The basic idea is that an individual ex ante has to face the increase in expected harm that may result from his behavior. This can only be accomplished if the judicial consequences of an actor's tortious behavior tend to be predictable and follow efficiency considerations. To that end we suggested the following approach. Let each actor know that upon the occurrence of harm ex post the court will start a reconstruction of the decision-making situation prior to the occurrence of the harm and will apportion actual harm in a way that ex ante would have produced efficient incentives in the case under consideration. Applying this approach, we showed that an apportionment rule where each tortfeasor pays a fraction of the actual harm that corresponds to his proportional contribution to the ultimate risk, always yields efficient incentives in cases of additive causal risks. This result obtains irrespective of whether multiple causation takes the form of causal uncertainty or joint causation. In non-additive cases the proportional rule has an efficient equilibrium outcome (and this equilibrium is unique for almost all parameter settings) when tortfeasors act independently and simultaneously, provided a third party (the government, an equalization fund) is allowed to collect or make up for any difference between the total apportionment of damages and actual harm. Proportional apportionment does not always provide efficient incentives when tortfeasors act in concert. Joint liability would then be the better apportionment rule. Nor does proportional apportionment always provide efficient incentives when tortfeasors act sequentially and the first actor can take the situation as he finds it, not anticipating (and being held liable for) any tortious act following his own.

To be sure, this paper did not give all of the answers on the application of tort law in cases of multiple causation. The analysis centered on the ex ante

${ }^{19}$ A related case is Fitzgerald v. Lane and another, [1988] 2 All ER 961. Fitzgerald walked onto a pelican street crossing while the lights were red for pedestrians and green for traffic. He was first hit by A's car, and then by B's car. Both drivers were found to have been traveling too fast and not keeping a proper look-out for pedestrians. The House of Lords decided that Fitzgerald was substantially the author of his own misfortune. His share in the responsibility was at least as great as that of the two drivers jointly, thus entitling him to recover no more than $50 \%$ in damages. From our perspective, the victim should be held fully responsible for his losses, while the car drivers, if indeed found to have been careless, should pay full damages to a third party. 


\section{Additive and Non-Additive Risk Factors in Multiple Causation / 539}

efficiency implications of the apportionment rule in a rather general theoretical setting, leaving aside more specific details that would initiate the familiar discussions on the pros and cons of negligence versus strict liability and on the relevance of distinguishing the level of care from the level of activities. We also avoided any empirical consideration of maybe rather limited preventive, deterrent effects of tort law in actual practice. We further refrained from any speculation on the potential implications for the number of trials and legal costs expost. These are elements for future research.

\section{References}

Ben-Shahar, Omri. 2000. "Causation and Forseeability," in B. Bouckaert and G. De Geest, eds. Encyclopedia of Law and Economics, vol. II. Cheltenham/Northampton, MA: Edward Elgar, 644-668.

Kornhauser, Lewis A., and Richard L. Revesz. 1989. "Sharing Damages Among Multiple Tortfeasors," 98 Yale Law Journal 831-884. and _. 2000. "Joint Tortfeasors," in B. Bouckaert and G. De Geest, eds. Encyclopedia of Law and Economics, vol. II. Cheltenham/Northampton, MA: Edward Elgar, 625-643.

Landes, William M., and Richard A. Posner. 1980. "Joint and Multiple Tortfeasors: An Economic Analysis," 9 Journal of Legal Studies 517-555.

Miceli, Thomas J., and Kathleen Segerson. 1991. "Joint Liability in Torts: Marginal and Infra-Marginal Efficiency," 11 Int'l Review of Law and Economics 235-249.

Parisi, Francesco, and Vincy Fon. 2004. "Comparative Causation," 6 American Law and Economics Review 345-368.

Rizzo, Mario J., and Frank S. Arnold. 1980. "Causal Apportionment in the Law of Torts: An Economic Theory," 80 Columbia Law Review 1399-1429.

Rogers, W.V.H. 2006. Winfield and Jolowicz on Tort, 16th ed. London: Sweet \& Maxwell.

Rothman, Kenneth J., Sander Greenland, and Timothy L. Lash. 2008. Modern Epidemiology, 3rd ed. Philadelphia, PA: Lippincott Williams \& Wilkins.

Shavell, Steven. 1985. "Uncertainty over Causation and the Determination of Civil Liability," 28 Journal of Law and Economics 587-609. . 2004. Foundations of Economic Analysis of Law. Cambridge MA/London: Harvard University Press.

Young, Robert, Michael Faure, and Paul Fenn. 2004. "Causality and Causation in Tort Law," 24 International Review of Law and Economics 507-523. , and Jonathan Willis. 2007. "Multiple Tortfeasors: An Economic Analysis," 3 Review of Law and Economics 111-132.

DOI: $10.2202 / 1555-5879.1340$ 